\title{
In vitro and in vivo effects of ribavirin on human respiratory epithelium
}

\author{
LY Han, R Wilson, S Slater, A Rutman, RC Read, NJC Snell, PJ Cole
}

\begin{abstract}
The effects of ribavirin, a broad spectrum antiviral agent, on the structure and function of normal human nasal epithelium have been studied in vitro, as has also the in vivo effect of treatment with nebulised ribavirin on nasal mucociliary clearance of saccharin in four patients. Ciliary beat frequency was measured by a photometric technique, and changes in epithelial and ciliary ultrastructure were assessed by transmission electron microscopy. Ribavirin solution at the recommended concentration of $20 \mathrm{mg} / \mathrm{ml}$ had no adverse effects on ciliary activity in vitro; at concentrations of $50 \mathrm{mg} / \mathrm{ml}$ and above it slowed ciliary beating significantly and at $60 \mathrm{mg} / \mathrm{ml}$ caused ciliostasis associated with epithelial disruption. Nasal inhalation of ribavirin at $\mathbf{6 0}$ $\mathrm{mg} / \mathrm{ml}$ for up to 20 minutes, however, did not slow nasal mucociliary clearance, nor did it adversely affect the ciliary beating or structure of nasal ciliated epithelium examined in vitro immediately after inhalation.
\end{abstract}

Ribavirin (1-beta-D-ribofuranosyl-1,2,3,4-triazol-3-carboxamide: Virazid) is a nucleoside analogue of guanosine and possesses broad spectrum antiviral activity against many RNA and DNA viruses. ${ }^{12}$ It is established in the United States and Britain as treatment for respiratory syncytial virus infection and when given for this purpose is administered as a small particle aerosol at a concentration of $20 \mathrm{mg} / \mathrm{ml}$ in distilled water. Continuous exposure of rhesus monkey tracheal organ culture to ribavirin at a concentration of $100 \mu \mathrm{g} / \mathrm{ml}$ for up to one month has been shown to have no effect on ciliary activity. ${ }^{3}$ The toxicity of ribavirin for human respiratory epithelium, however, has not been determined, though reversible minor reductions in indices of pulmonary function have been noted in adults with chronic obstructive lung disease and asthma after administration of ribavirin aerosol under experimental conditions. $^{45}$

The present study examined the in vitro effects of ribavirin on normal human nasal epithelium by light and transmission electron microscopy and the in vivo effect on nasal mucociliary clearance in adult patients given aerosolised ribavirin.

\section{Methods}

PREPARATION OF RIBAVIRIN SOLUTIONS

Ribavirin was supplied in pure lyophilised crystalline form with no preservative by Viratek (ICN Pharmaceuticals Ltd) and reconstituted in distilled water $(20,40,60,80$, and $100 \mathrm{mg} / \mathrm{ml}$ ). Osmolalities were measured with an Advanced Micro-osmometer, model $3 \mathrm{MO}$ (Advances Instruments Inc). There was a linear relation between osmolality and drug concentration. The osmolality was $78 \mathrm{mmol} / \mathrm{kg}$ at $20 \mathrm{mg} / \mathrm{ml}$ and $348 \mathrm{mmol} / \mathrm{kg}$ at $100 \mathrm{mg} / \mathrm{ml}$. The osmolality at $80 \mathrm{mg} / \mathrm{ml}$ was near to physiological values at $280 \mathrm{mmol} / \mathrm{kg}$ and this concentration of solution was chosen for further dilution with Dulbecco's phosphate buffered saline (osmolality $285 \mathrm{mmol} / \mathrm{kg}$ ) without calcium, magnesium, or bicarbonate (Gibco Ltd) to provide ribavirin $(20,40,50,60$, and 80 $\mathrm{mg} / \mathrm{ml}$ ) for use in the in vitro experiments. The osmolality of each test solution was checked before each experiment (range 280-301 mmol/ $\mathrm{kg}$ ).

The $\mathrm{pH}$ of ribavirin $(20-100 \mathrm{mg} / \mathrm{ml})$ in distilled water ranged from $5 \cdot 0$ to $5 \cdot 5$. The $\mathrm{pH}$ of the parent solution $(80 \mathrm{mg} / \mathrm{ml})$ was adjusted to 7.0 using $0.1 \mathrm{M}$ sodium hydroxide before dilution with phosphate buffered saline $(\mathrm{pH}$ $7 \cdot 2$ ) because reduction in ciliary beat frequency has been observed at a $\mathrm{pH}$ below 6.7 and above $9 \cdot 8 .^{67}$

IN VITRO EFFECT OF RIBAVIRIN ON CILIARY FUNCTION

Strips of ciliated epithelium were obtained from the inferior nasal turbinates of healthy normal volunteers by a brushing technique not requiring local anaesthesia ${ }^{8}$ and were dispersed by agitation in medium 199 cell culture fluid (Flow Laboratories).

The suspension of ciliated epithelium was divided into two or three equal aliquots and centrifuged $(180 \mathrm{~g})$ for 5 minutes. The supernatant medium 199 was aspirated and replaced by an equal volume $(300 \mu \mathrm{l})$ of phosphate buffered saline in one sample (control) and varying ribavirin concentrations in the others (test). Each suspension of ciliated epithelium was immediately transferred to a sealed microscope coverslip-slide preparation with a pipette and placed on an electrically controlled warmstage (Microtec) at $37^{\circ} \mathrm{C}$ for measurement of ciliary beat frequency by a photometric technique, ${ }^{8}$ an automated ciliary beat frequency processor unit being used. ${ }^{9}$ The observer was 
unaware of the drug concentration in each slide. Initially, each preparation was allowed to equilibrate to $37^{\circ} \mathrm{C}$ over 10 minutes. During this period at least six strips of ciliated epithelium were identified and the slide was marked so that serial readings of ciliary beat frequency could be taken from the same strips throughout the experiment. Single ciliated cells and small groups of ciliated cells were not used because readings from such areas are inconsistent. Ten ciliary beat frequency readings were then taken (each epithelial strip being used and no more than two readings being taken from any strip) and designated as being taken at time zero. Subsequent readings were taken hourly for five hours; at each time readings were taken as near as possible to the sites of previous recordings.

At each time the mean of the 10 readings was calculated. When all cilia on a marked strip ceased to beat the ciliary beat frequency was recorded as zero, but if any cilia on a strip remained beating the ciliary beat frequency of the moving cilia was measured. A note was made of any ciliary dyskinesia (disturbance of the normal ordered pattern of ciliary beating), ciliostasis, or epithelial disruption (breakdown of the integrity of a strip into smaller groups of cells) during ciliary beat frequency recordings.

IN VITRO EFFECT OF RIBAVIRIN ON EPITHELIAL STRUCTURE MEASURED BY TRANSMISSION ELECTRON MICROSCOPY

Ciliated epithelial tissue was obtained by surgical resection of inferior turbinates from patients with chronic nasal obstruction. The tissue was transported to the laboratory in Minimal Essential Medium (Gibco Ltd) supplemented with penicillin 50 units $/ \mathrm{ml}$, streptomycin $50 \mu \mathrm{g} / \mathrm{ml}$ and gentamicin $60 \mu \mathrm{g}$ / $\mathrm{ml}$ (MEM-ATB). The turbinates were then cut into four $3 \mathrm{~mm}$ thick adjacent cross sections, immersed in control phosphate buffered saline or three different solutions of ribavirin $(20,40$, and $80 \mathrm{mg} / \mathrm{ml}$ ) prepared as previously described, and incubated for four hours at $37^{\circ} \mathrm{C}$ They were then gently removed and immersed in cacodylate buffered $2.5 \%$ gluteraldehyde, and then postfixed in $1 \%$ osmium tetroxide before being processed through to embedding in Araldite. Semithin sections $1 \mu \mathrm{m}$ thick were cut and stained in 1\% toluidine blue in borax for light microscopy and suitable areas were selected and trimmed for ultrathin sectioning. These were stained in uranyl acetate and lead citrate for transmission electron microscopy. Epithelial ultrastructure was examined by an observer, unaware of how each specimen had been treated, who scored the sections for cell protrusion from the epithelial surface, cytoplasmic blebbing, cells with mitochondrial damage, dead cells, and degree of ciliation. The number of cells displaying a particular abnormality was compared with the number of cells without this abnormality in test and control preparations.

IN VIVO EFFECT OF AEROSOLISED RIBAVIRIN ON NASAL MUCOCILIARY CLEARANCE

We studied four patients with cryptogenic fibrosing alveolitis (three of them male), aged 55 to 67 years, as they started treatment with aerosolised ribavirin three times a day. ${ }^{10}$ The patients had not responded to conventional treatment of their disease with corticosteroids and immunosuppressive drugs. Each received $240 \mathrm{mg}$ of ribavirin dissolved in $4 \mathrm{ml}$ of distilled water (concentration $60 \mathrm{mg} / \mathrm{ml}$, osmolality 210 $\mathrm{mmol} / \mathrm{kg}, \mathrm{pH} 5 \cdot 0-5 \cdot 5)$ nebulised by oxygen at 9 1/min for 15-20 minutes. For the experiments the aerosol was delivered via a facemask and the patient was asked to inhale through the nose alone. Nasal mucociliary clearance was measured by the saccharin test ${ }^{11}$ four hours before administration of ribavirin. The time from placing a $1 \mathrm{~mm}$ particle of saccharin on the inferior nasal turbinate $(1 \mathrm{~cm}$ from its anterior end) to the subject's first experience of a sweet taste was recorded in minutes. The subjects were positioned with the head tilted $10^{\circ}$ down and forward and requested not to sniff, sneeze, cough, eat, or drink during the tests. The test was repeated on the same nostril 30 minutes after they had finished inhaling the ribavirin aerosol. Nasal brushings were obtained from the same nostril immediately after the test and examined in vitro by light microscopy for ciliary beat frequency and structural integrity.

\section{ANALYSIS}

For each ciliary beat frequency experiment the mean of 10 ciliary beat frequencies was calculated at each time point for test and control preparations. The mean ciliary beat frequency of the test preparation at five hours was compared with the control mean at the same time to obtain a percentage of the control ciliary beat frequency for each experiment. The paired Student's $t$ test was used to compare mean ciliary beat frequencies at each concentration of ribavirin.

\section{Results}

Cilia beat normally in control phosphate buffered saline for up to five hours. Slowing of ciliary beat frequency and subsequent ciliostasis occurred almost immediately in the hypo-osmolar $(82 \mathrm{mmol} / \mathrm{kg})$ ribavirin solution of $20 \mathrm{mg} / \mathrm{ml}$ at $\mathrm{pH} 5.5$ and by two hours ciliostasis had occurred on all epithelial strips. This effect was less pronounced after correction of $\mathrm{pH}$ to $7 \cdot 0$, but ciliostasis was complete in all strips by five hours. Subsequent experiments were carried out with ribavirin solutions corrected to physiological $\mathrm{pH}$ and osmolality as described previously.

\section{IN VITRO CILIARY BEAT FREQUENCY}

Mean ciliary beat frequencies expressed as percentages of the control values over a five hour period at the five drug concentrations are shown in figure 1. More experiments were performed at 40 and $50 \mathrm{mg} / \mathrm{ml}$ (six each) because initial results suggested that borderline toxicity probably lay within this range. Ribavirin $20 \mathrm{mg} / \mathrm{ml}$ (the concentration used therapeutically) had no effect on ciliary beat frequency over the five hours. At a concentration of $40 \mathrm{mg} / \mathrm{ml}$ the mean (SD) reduction in 
Figure 1 Effect of various concentrations of in vitro ribavirin on ciliary beat frequency over five

hours.

$\square 20 \mathrm{mg} / \mathrm{ml}(n=3)$;

$040 \mathrm{mg} / \mathrm{ml}(\mathrm{n}=6)$

$50 \mathrm{mg} / \mathrm{ml}(n=6)$

$\triangle 60 \mathrm{mg} / \mathrm{ml}(n=3)$

$\Delta 80 \mathrm{mg} / \mathrm{ml}(\mathrm{n}=3)$.

$n$-number of experiments

performed, each yielding

10 ciliary beat frequency

readings at each time

point. Bar lines denote

standard deviations.

$\star$ Ciliostasis. ${ }^{\star} p<0.025$;

${ }^{\star} p<0.01$, with reference

to control values

(Student's $t$ test).

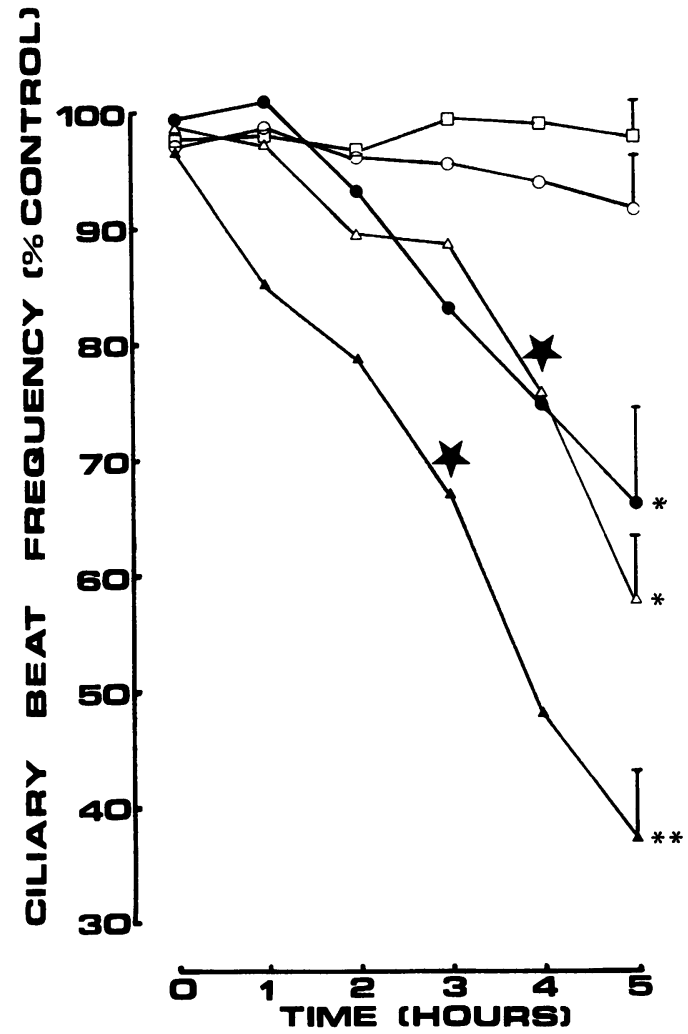

ciliary beat frequency was $8 \cdot 4 \%(12 \cdot 8 \%)$, at 50 $\mathrm{mg} / \mathrm{ml} 33.5 \%(21.1 \%)$, at $60 \mathrm{mg} / \mathrm{ml} 42.1 \%$ $\left(10 \cdot 7{ }_{0}\right)$, and at $80 \mathrm{mg} / \mathrm{ml} 62.8 \%(9 \cdot 7 \%)$. The effect on ciliary beat frequency appeared to be dose related (fig 1). At concentrations of 40 $\mathrm{mg} / \mathrm{ml}$ or less there was a mean reduction in ciliary beat frequency in only four of the nine experiments (one of three experiments at 20 $\mathrm{mg} / \mathrm{ml}$ and three of six experiments at $40 \mathrm{mg} /$ $\mathrm{ml})$. In contrast, at concentrations of $50 \mathrm{mg} / \mathrm{ml}$ or more there was a reduction in ciliary beat frequency in all 12 experiments $(p<0.001$, sign test). Concentrations of $60 \mathrm{mg} / \mathrm{ml}$ and 80 $\mathrm{mg} / \mathrm{ml}$ caused significant slowing of ciliary beat frequency in all experiments; ciliostasis was first noted at four hours and three hours respectively. Ciliary dyskinesia was not observed in any of the experiments.

\section{LIGHT MICROSCOPY OF CILIATED EPITHELIUM}

After five hours $20 \mathrm{mg} / \mathrm{ml}$ of ribavirin did not cause any change in epithelial structure. At 40 $\mathrm{mg} / \mathrm{ml}$ disruption of the epithelium resulted in irregularity of the epithelial margin and at 50 $\mathrm{mg} / \mathrm{ml}$ extrusion of cells or cell material could be seen. Such changes became more pronounced at the higher concentrations of 60 and 80 $\mathrm{mg} / \mathrm{ml}$. These observations were made hourly over the five hours during which ciliary beat frequency estimations were taken.

\section{ULTRASTRUCTURE OF CILIATED EPITHELIUM} (fig 2)

Table 1 shows changes in epithelial cell ultrastructure as viewed by transmission electron microscopy after four hours' exposure to ribavirin. At 20 and $40 \mathrm{mg} / \mathrm{ml}$ these changes were mild but at $80 \mathrm{mg} / \mathrm{ml}$ they were gross, consisting of cytoplasmic blebbing, mitochondrial damage, projection of cells from the epithelial surface, vacuolation, and appearance of dead and unhealthy cells. The microtubule arrangement and dynein arms of the cilia were assessed in each solution and found to be normal.

NASAL MUCOCILIARY CLEARANCE AND CILIARY BEAT FREQUENCY AFTER IN VIVO RIBAVIRIN AEROSOL

The results of the in vivo studies in the four patients (table 2) indicated no adverse effect of ribavirin on nasal mucociliary clearance or on the light microscopic appearances of the epithelial structure of the nasal brushings after exposure to aerosolised ribavirin. The mean ciliary beat frequencies of the nasal brushings lay within the normal range $(11-17 \mathrm{~Hz}) .^{12}$

\section{Discussion}

Ribavirin has been shown to produce clinical benefit in the treatment of respiratory syncytial virus infections in children ${ }^{1314}$ and influenza in adults ${ }^{15-17}$ when administered as a small particle aerosol. Efficacy of oral ribavirin in the treatment of measles has been reported, ${ }^{18}$ and it is also effective in Lassa fever when given either orally or intravenously. ${ }^{19}$ Ribavirin has been shown to suppress the replication of human immunodeficiency virus in human adult $T$ lymphocytes in vitro. ${ }^{20}$ Studies of the efficacy of ribavirin in the treatment of the acquired immunodeficiency syndrome, the AIDS related complex, ${ }^{21}$ and persistent generalised lymphadenopathy ${ }^{22}$ are therefore being conducted. Two months' ribavirin aerosol treatment of a patient with desquamative interstitial pneumonia was apparently associated with dramatic improvement in clinical wellbeing and improvement in pulmonary physiology after no such improvement from treatment with corticosteroids and azathioprine for the previous five years or from acyclovir for almost one year. ${ }^{10}$ Clinical studies of aerosolised ribavirin in patients with cryptogenic fibrosing alveolitis are now in progress.

The manufacturers recommend dissolving ribavirin in distilled water for administration by nebuliser. We have found that such solutions are acidic and, in concentrations below 80 $\mathrm{mg} / \mathrm{ml}$, hypo-osmolar. Our initial experiment

Table 1 In vitro effects of ribavirin on the ultrastructure of nasal ciliated epithelium

\begin{tabular}{|c|c|c|c|c|c|c|}
\hline $\begin{array}{l}\text { Drug conc } \\
(\mathrm{mg} / \mathrm{ml})\end{array}$ & $\begin{array}{l}\text { Total No } \\
\text { of cells } \\
\text { examined }\end{array}$ & $\begin{array}{l}\text { oo ciliated } \\
\text { cells }\end{array}$ & $\begin{array}{l}\text { o dead and } \\
\text { unhealthy } \\
\text { cells }\end{array}$ & $\begin{array}{l}{ }_{o} \text { cells } \\
\text { projecting } \\
\text { from ciliated } \\
\text { epithelium }\end{array}$ & $\begin{array}{l}{ }_{0}^{o} \text { cells with } \\
\text { mitochondrial } \\
\text { damage }\end{array}$ & $\begin{array}{l}{ }_{0}^{o} \text { cells with } \\
\text { cytoplasmic } \\
\text { blebbing }\end{array}$ \\
\hline $\begin{array}{l}\text { PBS (control) } \\
20 \\
40 \\
80\end{array}$ & $\begin{array}{l}225 \\
218 \\
285 \\
112\end{array}$ & $\begin{array}{l}68 \cdot 9 \\
68 \cdot 3 \\
88 \cdot 1 \\
73 \cdot 2\end{array}$ & $\begin{array}{l}0 \\
1 \cdot 83 \\
0 \cdot 35 \\
4 \cdot 46\end{array}$ & $\begin{array}{r}2 \cdot 7 \\
17 \cdot 4 \\
17 \cdot 2 \\
42 \cdot 0\end{array}$ & $\begin{array}{r}0 \cdot 9 \\
7 \cdot 0 \\
6 \cdot 7 \\
32 \cdot 7\end{array}$ & $\begin{array}{r}1 \cdot 8 \\
10 \cdot 3 \\
9 \cdot 6 \\
24.3\end{array}$ \\
\hline
\end{tabular}

PBS-phosphate buffered saline. 
Figure 2 Electron micrographs showing ultrastructural changes in ciliated nasal epithelium caused by in vitro exposure to ribavirin for four hours. (a) Phosphate buffered saline: normal epithelium. (b) Ribavirin $20 \mathrm{mg} / \mathrm{ml}$ : cytoplasmic blebbing and mitochondrial damage appearing. (c) Ribavirin $40 \mathrm{mg} / \mathrm{ml}$ : protrusion of ciliated cell from

epithelium, vacuolation and gross mitochondrial damage. (d) Ribavirin 80 $\mathrm{mg} / \mathrm{ml}$ : dark staining unhealthy cell separating at cell junction and extrusion of cell material.
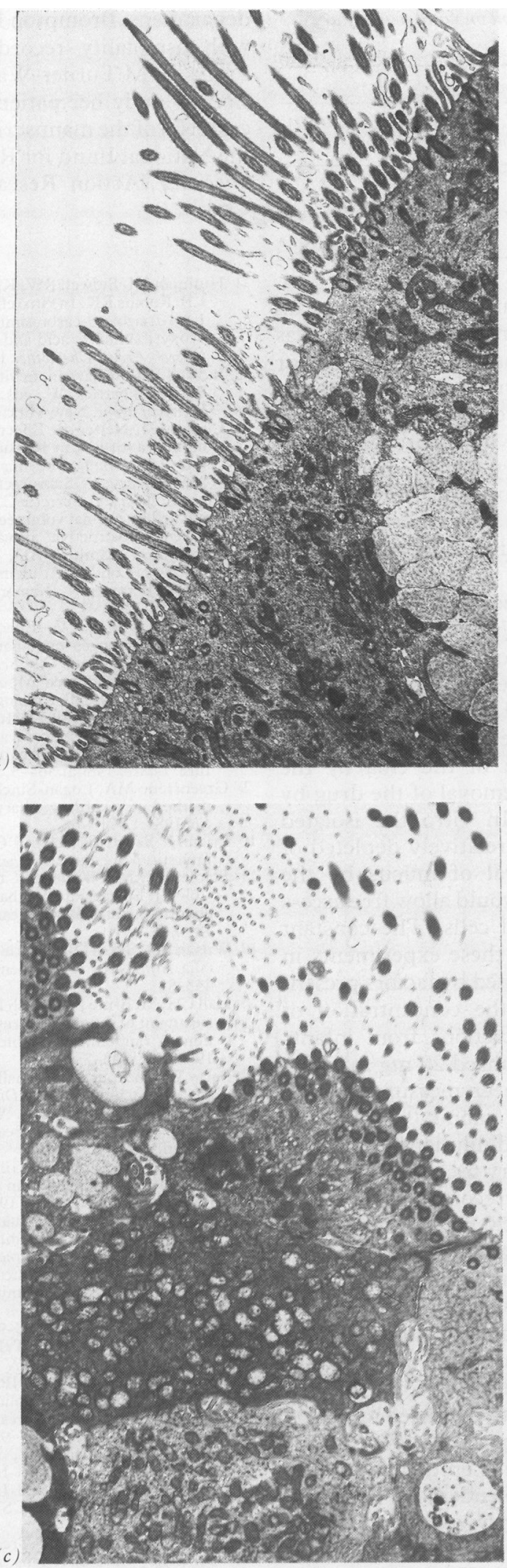

showed that low $\mathrm{pH}(5 \cdot 5)$ and low osmolality $(80 \mathrm{mmol} / \mathrm{kg}$ ) caused slowing of ciliary beat frequency and ciliostasis in vitro, which is consistent with the findings of previous workers. ${ }^{67}$ Hypotonic and hypertonic nebulised solutions have been shown to cause a significant fall in $\mathrm{FEV}_{1}$ in asthmatic subjects, ${ }^{23}$ and it is relevant here that mast cells release histamine when placed in hypotonic solutions. ${ }^{24}$ Interestingly, ribavirin inhibits release of mediators from mast cells in vitro. ${ }^{25}$ Recently acidity has been shown to potentiate the

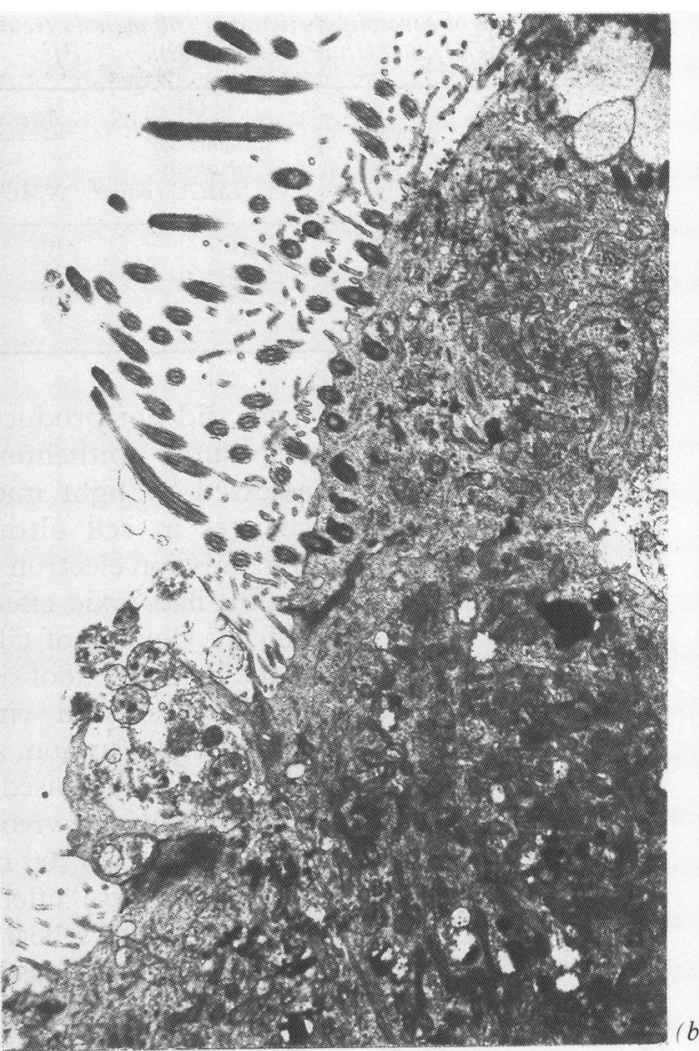

bronchoconstriction caused by inhalation of a hypo-osmolar aerosol in subjects with asthma. ${ }^{26}$ We suggest that the low $\mathrm{pH}$ and low osmolality of ribavirin when dissolved in distilled water may be the reason for the modest and reversible deterioration in respiratory function tests reported in adults with chronic obstructive airways disease and asthma after they have inhaled the drug.

After correction of $\mathrm{pH}$ and osmolality to physiological values, the concentration (20 $\mathrm{mg} / \mathrm{ml}$ ) of ribavirin recommended for treat- 
Table 2 Effects of aerosolised ribavirin $(60 \mathrm{mg} / \mathrm{ml})$ treatment on nasal mucociliary clearance (NMCC) and ciliary beat frequency (CBF)

\begin{tabular}{|c|c|c|c|c|c|}
\hline \multirow[b]{2}{*}{ Patient } & \multirow[b]{2}{*}{ Sex } & \multirow[b]{2}{*}{$\begin{array}{l}\text { Age } \\
(y)\end{array}$} & \multirow{2}{*}{$\begin{array}{l}\text { Before } \\
\text { ribavirin } \\
\text { NMCC }(\text { min })^{\star}\end{array}$} & \multicolumn{2}{|l|}{ After ribavirin } \\
\hline & & & & $N M C C(\min )$ & $\begin{array}{l}\text { Mean } C B F(\mathrm{~Hz}) \dagger \\
(n=10)\end{array}$ \\
\hline $\begin{array}{l}\text { A } \\
\text { B } \\
\text { C } \\
\text { D }\end{array}$ & $\begin{array}{l}\mathrm{F} \\
\mathrm{M} \\
\mathrm{M} \\
\mathrm{M}\end{array}$ & $\begin{array}{l}55 \\
64 \\
61 \\
67\end{array}$ & $\begin{array}{l}21 \\
22 \\
25 \\
19\end{array}$ & $\begin{array}{l}10 \\
21 \\
16 \\
15\end{array}$ & $\begin{array}{l}11 \cdot 2 \\
12 \cdot 7 \\
14 \cdot 3 \\
14 \cdot 2\end{array}$ \\
\hline
\end{tabular}

«Normal range $<30 \mathrm{~min}$

†Normal range $11-17 \mathrm{~Hz}$

ment did not produce any adverse effects on respiratory epithelium in vitro when this was assessed by light microscopy, though minor changes in cell ultrastructure were seen by transmission electron microscope. Probably 40 $\mathrm{mg} / \mathrm{ml}$ had toxic effects in vitro because significant slowing of ciliary beat frequency was noted in three out of six experiments. At higher concentrations in vitro the ciliary slowing, epithelial disruption, and changes in cell ultrastructure all increased.

Our results in vivo, however, indicate that ribavirin aerosol $(60 \mathrm{mg} / \mathrm{ml}$ in distilled water) had no adverse effect on nasal mucociliary clearance, ciliary beat frequency, or epithelial cell structure as assessed by light microscopy. This may be due to the dilutional effects of nasal mucus, protection of the cilia by the blanket of mucus, and removal of the drug by mucociliary clearance. In vitro the isolated epithelial strips may be relatively depleted of mucus owing to removal of mucus by the culture medium, which would allow free access of the drug to epithelial cells. The constant exposure to the drug in these experiments in vitro would not be mitigated by factors present in vivo. For example, the concentration of ribavirin in tracheal secretions from infants after inhalation of a nebulised $20 \mathrm{mg} / \mathrm{ml}$ solution for eight hours has been measured as 1.0 $7 \cdot 7 \mathrm{mmol} / 1,{ }^{27}$ equivalent to about $0.25-1.7 \mathrm{mg} /$ $\mathrm{ml}$; this suggests a 20 fold dilution of the original solution by respiratory tract secretions.

We conclude that the recommended therapeutic dose of ribavirin $(20 \mathrm{mg} / \mathrm{ml})$ is unlikely to cause epithelial damage in vivo. This concentration produced minor changes in epithelial cells in vitro, which were seen by electron microscopy, though not by light microscopy, but which did not affect ciliary beat frequency. Protection of the epithelium by mucus and dilution of the inhaled drug by mucosal fluids probably mean that the concentration of the drug to which epithelial cells are exposed in vivo is considerably reduced, though this may be partly offset where the mucosa is damaged. Our results in four patients taking the aerosolised drug $(60 \mathrm{mg} / \mathrm{ml})$ support this view. Further studies, however, are required to investigate the effects of prolonged administration of ribavirin on respiratory epithelium.

We recommend that ribavirin should be administered at physiological osmolality and $\mathrm{pH}$, at least to patients with variable airflow obstruction.

We thank Viratek (ICN Pharmaceuticals Ltd) for supplying ribavirin and $\mathrm{Mr} M$ Kemp and Mr S Nagarajah of the chemical pathology department, Brompton Hospital, for their help with osmolality recordings. We also thank Professor M Turner-Warwick for kind permission to study her patients and for her helpful criticism of the manuscript. RR is supported by the National Fund for Research into Crippling Diseases (Action Research for the Crippled Child).

1 Huffman JH, Sidwell RW, Khane GP, Witkowski JT, Allen LB, Robins RK. In vitro effect of 1-beta-D-ribofuranosyl1,2,4-triazole-3-carboxamide (Virazole, ICN 1229) on deoxyribonucleic acid and ribonucleic acid viruses. Antimicrob Agents Chemother 1973;35:235-41.

2 Sidwell RW. Ribavirin: in vitro antiviral activity. In: Smith RA, Kirkpatrick W, eds. Ribavirin: a broad spectrum antiviral agent. New York: Academic Press, 1980;23-42.

3 Lindsay $\mathrm{H}$, Nelsen $\mathrm{B}$. Effect of ribavirin on replication of influenza viruses in Rhesus monkey tracheal organ cultures. In: Annual meeting of the American Society for Microbiology. 1975:abstract A28.

4 Light B, Aoki FY, Serrette C. Tolerance of ribavirin aerosol inhaled by normal volunteers and patients with asthma or chronic obstructive airways disease. In: Smith RA Knight V, Smith JAD, eds. Clinical applications of ribavirin. London: Academic Press, 1984:97-105.

5 Liss HP, Bernstein J. Ribavirin aerosol in the elderly. Chest 1988;93:1239-41.

6 Luk CK, Dulfano $M$. Effect of $\mathrm{pH}$, viscosity and ionic strength changes on ciliary beat frequency of human bronchial explants. Clin Sci 1983;64:449-51.

7 Holma BO, Lindegren M, Andersen JM. pH effects on ciliomotility and morphology of respiratory mucosa. Arch Environ Health 1979;32:216-26.

8 Rutland J, Cole PJ. Non-invasive sampling of nasal cilia fo measurement of beat frequency and study of ultrastructure. Lancet 1980;ii:564-5.

9 Greenstone MA, Logan-Sinclair R, Cole PJ. An automated method of recording ciliary beat frequency. IRCS Med Sci $1984 ; 12: 715-6$.

10 Prieto J, Sango B, Beloqui O. Ribavirin in desquamative interstitial pneumonia. Chest 1988;93:446-7.

11 Stanley PJ, MacWilliam L, Greenstone MA, Mackay IS Cole PJ. Efficacy of a saccharin test for screening to detect abnormal mucociliary clearance. Br J Dis Chest 1984 78:62-5.

12 Wilson RA, Sykes DA, Currie D, Cole PJ. Beat frequency of cilia from sites of purulent infection. Thorax 1986;41: 453-8.

13 Hall CH, McBride JT, Walsh EE, et al. Aerosolised ribavirin treatment of infants with respiratory syncytial viral infection. A randomized double blind study. $N$ Engl J Med 1983;308:1443-7.

14 Barry W, Cockburn F, Cornall R, et al. Ribavirin aerosol for acute bronchiolitis. Arch Dis Child 1986;61:593-7.

15 Knight V, McClung HW, Wilson SZ, et al. Ribavirin. Small-particle aerosol treatment of influenza. Lancet Small-particle

16 McClung HW, Knight V, Gilbert BE, Wilson SZ, Quarles JM, Divine GW. Ribavirin aerosol treatment of influenz $\mathrm{B}$ virus infection. $J A M A$ 1983;19:2671-4

17 Wilson SZ, Gilbert BE, Quarles JM, et al. Treatment of influenza $A\left(H_{1} N_{1}\right)$ virus infection with ribavirin aerosol. Antimicrob Agents Chemother 1984;2:200-3.

18 Banks G, Fernandez $\mathrm{H}$. Clinical use of ribavirin in measles: a summarized review. In: Smith RA, Knight V, Smith JAD, eds. Clinical applications of ribavirin. New York: eds. Clinical applications

19 McCormick JB, King IJ, Welsh PA. Lassa fever: effective treatment with ribavirin. N Engl J Med 1986;314:20-6.

20 McCormick JB, Getchell JP, Mitchell SW, Hicks DR Ribavirin suppresses replication of lymphadenopathy associated virus in cultures of human adult T-lymphocytes. Lancet 1984;ii:1367-9.

21 Crumpacker C, Heagy W, Bubley G, et al. Ribavirin treatment of the Acquired-Immunodeficiency-Syndrome (AIDS) and the Acquired-Immunodeficiency-Syndrome Related Complex (ARCS). Ann Intern Med 1987; 107:664-74.

22 Hirsh MS, Kaplan JC. Treatment of human immunodeficiency virus infections. Antimicrob Agents Chemother 1987;31:839-43.

23 Schoeffel RE, Anderson SD, Altounya RE. Bronchial reactivity in response to inhalation of ultrasonically nebulised solutions of distilled water and saline. Br Med J 1981; ised solutions of distilled water and saline. Br Med J 1981;

24 Kaliner M, Austen KF. Cyclic AMP, ATP and reversed anaphylactic histamine release from rat mast cells. $J$ anaphylactic histamine re

25 Marquardt DL, Gruber HE, Walker LL. Ribavirin inhibits mast cell mediator release. J Pharmacol Exp Ther 1987;240:145-9.

26 Balmes JR, Fine JM, Christian D, Gordon T, Steppard D. Acidity potentiates bronchoconstriction induced by hypoosmolar aerosols. Am Rev Respir Dis 1988;138:35-9.

27 Connor J, Hintz M, van Dyke R, McCormick J, McIntosh $\mathbf{K}$. Ribavirin pharmacokinetics in children and adults during therapeutic trials. In: Smith RA, Knight V, Smith JAD, eds. Clinical applications of ribavirin. New York: Academic Press, 1984: 107-23. 